\title{
Predicting early brain metastases based on clinicopathological factors and gene expression analysis in advanced HER2-positive breast cancer patients
}

\author{
Renata Duchnowska · Jacek Jassem • Chirayu Pankaj Goswami · \\ Murat Dundar · Yesim Gökmen-Polar $\cdot$ Lang Li $\cdot$ Stephan Woditschka \\ Wojciech Biernat • Katarzyna Sosińska-Mielcarek • Bogumiła Czartoryska-Arłukowicz • \\ Barbara Radecka Zorica Tomasevic $\cdot$ Piotr Stępniak $\cdot$ Konrad Wojdan • \\ George W. Sledge Jr. • Patricia S. Steeg $\cdot$ Sunil Badve
}

Received: 24 August 2014/Accepted: 21 December 2014/Published online: 6 January 2015

(C) The Author(s) 2015. This article is published with open access at Springerlink.com

\begin{abstract}
The overexpression or amplification of the human epidermal growth factor receptor 2 gene (HER2/ $n e u)$ is associated with high risk of brain metastasis (BM). The identification of patients at highest immediate risk of BM could optimize screening and facilitate interventional trials. We performed gene expression analysis using complementary deoxyribonucleic acid-mediated annealing, selection, extension and ligation and real-time quantitative reverse transcription PCR (qRT-PCR) in primary tumor samples from two independent cohorts of advanced HER2 positive breast cancer patients. Additionally, we analyzed predictive relevance of clinicopathological factors in this
\end{abstract}

\section{R. Duchnowska ( $\square$ )}

Department of Oncology, Military Institute of Medicine,

Szaserów St 128, 04-141 Warsaw, Poland

e-mail:rdtt@wp.pl

J. Jassem

Department of Oncology and Radiotherapy, Medical University,

Gdańsk, Poland

C. P. Goswami - M. Dundar · L. Li

Center for Computational Biology and Bioinformatics,

Department of Medical and Molecular Genetics, Indiana

University School of Medicine, Indianapolis, IA, USA

Y. Gökmen-Polar · S. Badve

Departments of Medicine and Pathology and Laboratory

Medicine, Indiana University School of Medicine, Indianapolis,

IA, USA

S. Woditschka P. S. Steeg

Women's Cancers Section, Laboratory of Molecular

Pharmacology, Center for Cancer Research, National Cancer

Institute, Bethesda, MD, USA

\section{W. Biernat}

Department of Pathology and Oncology, Medical University,

Gdańsk, Poland series. Study group included discovery Cohort A (84 patients) and validation Cohort B (75 patients). The only independent variables associated with the development of early BM in both cohorts were the visceral location of first distant relapse [Cohort A: hazard ratio (HR) 7.4, $95 \% \mathrm{CI}$ 2.4-22.3; $p<0.001$; Cohort B: HR 6.1, $95 \%$ CI 1.5-25.6; $p=0.01]$ and the lack of trastuzumab administration in the metastatic setting (Cohort A: HR 5.0, $95 \%$ CI 1.4-10.0; $p=0.009$; Cohort B: HR 10.0, $95 \%$ CI 2.0-100.0; $p=0.008)$. A profile including 13 genes was associated with early ( $\leq 36$ months) symptomatic BM in the discovery cohort. This was refined by qRT-PCR to a 3 -gene classifier

K. Sosińska-Mielcarek

Regional Oncology Center, Gdańsk, Poland

B. Czartoryska-Arłukowicz

Department of Oncology, Oncology Center, Białystok, Poland

B. Radecka

Department of Oncology, Oncology Center, Opole, Poland

Z. Tomasevic

Institute for Oncology and Radiology, Belgrade, Serbia

P. Stępniak

Transition Technologies S.A., Warsaw, Poland

K. Wojdan

Institute of Heat Engineering, Warsaw University of

Technology, Warsaw, Poland

G. W. Sledge Jr.

Division of Oncology, Stanford University Medical Center, Stanford, CA, USA 
(RAD51, HDGF, TPR) highly predictive of early BM (HR 5.3, $95 \%$ CI 1.6-16.7; $p=0.005$; multivariate analysis). However, predictive value of the classifier was not confirmed in the independent validation Cohort B. The presence of visceral metastases and the lack of trastuzumab administration in the metastatic setting apparently increase the likelihood of early BM in advanced HER2-positive breast cancer.

Keywords Breast cancer - Brain metastasis - HER2 . $R A D 51 \cdot H D G F \cdot T P R$

\section{Introduction}

The overexpression or amplification of the human epidermal growth factor receptor 2 gene (HER2/neu) is associated with high risk of brain metastasis (BM). Approximately $30-50 \%$ of advanced HER2-positive breast cancer patients will develop BM, with an annual risk of around $10 \%$ [1-5]. It has been speculated that improvements in systemic therapy resulting in greater numbers and more durable systemic responses may permit more time for BM relapse. Trastuzumab, a monoclonal antibody that targets the extracellular domain of HER2, is used in combination with chemotherapy to improve the survival of patients with HER2-positive tumors [6-10]. However, owing to its high molecular weight, penetration of trastuzumab into the central nervous system is extremely low, 1/420th of serum levels [11], and this compound is ineffective in treating established BM.

The development of BM predictors in advanced breast cancer patients might have practical clinical implications. First, the use of imaging to detect occult BM in unselected patients is controversial, whereas this strategy may be reasonable in patients at highest immediate risk. Second, reliable predictive factors may improve selection of patients in clinical trials assessing the efficacy of putative BM prevention strategies, such as prophylactic cranial irradiation or the use of brain-permeable compounds. Finally, these studies may prompt new therapeutic strategies.

In the present study we analyzed the risk of early BM according to gene expression, and clinical and pathological variables in two well annotated cohorts of advanced HER2positive breast cancer patients.

\section{Materials and methods}

Patients

This study was approved by the Institutional Review Board of the coordinating centers (Medical University of Gdańsk,
Poland and Indiana University, USA). Two patient cohorts were derived from a consecutive series of 315 advanced HER2-positive breast cancer patients treated in nine oncology centers in Poland and Serbia between 1993 and 2010 (consort diagram; Fig. 1). Discovery Cohort A ( $n=167)$ and an independent validation Cohort B ( $n=148)$ were collected between 2006-2008 and 2008-2010, respectively. According to standard clinical practice, no screening for occult BMs was used, therefore almost all BM were symptomatic. BM were defined as metastatic lesions involving the brain parenchyma, with or without accompanying leptomeningeal disease. Demographic and clinicopathologic data, as well as treatments and clinical follow-up were extracted from institutional databases or original patient files. Treatments were rule based (Table 1). Dominant metastatic sites were assigned into three categories: soft tissue, bones and viscera. Dominant metastatic site was classified by the category associated with the worst prognosis in the following order of increasing gravidity: soft tissue, bones, viscera [12].

\section{Pathology review}

The starting material from each patient was a formalinfixed, paraffin embedded specimen of primary breast cancer. A pre-cut section of each tumor, stained with hematoxylin and eosin, was reviewed by two pathologists (SB and WB) to confirm the presence of sufficient invasive breast cancer component $\left(1 \mathrm{~cm}^{2}\right.$ invasive tissue, $\geq 30 \%$ tumor cells). In Cohorts A and B, 90/167 and 75/148 tumors, respectively, had sufficient material for molecular analysis. Expression of ER and PR was determined using immunohistochemistry (IHC), with $10 \%$ of nuclear staining considered as a positive result. HER2 protein expression was determined using semiquantitative IHC (HercepTest, Dako A/S, Glostrup, Denmark) or HER-2/ neuTest 4B5 (Ventana Medical Systems, Inc.). Only samples showing strong expression (scored $3+$ ), defined as uniform, and intense membrane staining of at least $10 \%$ of invasive tumor cells, were considered positive. The samples showing intermediate expression (scored 2+) were subjected to additional analysis of HER2 gene copy number using fluorescence in situ hybridization (FISH). Gene amplification by FISH was defined as a FISH ratio (HER2/ centromeric probe for chromosome 17 ratio) of greater than 2.0. FISH-positive patients were considered HER2positive.

\section{RNA extraction}

Tumor cells were processed using macrodissection to enrich their population for analysis. Sections were deparaffinized with CitriSolv clearing agent (Fisher Scientific 
Fig. 1 Consort diagram
Discovery Cohort A (material collected 2006-2008)

First step (DASL analysis; year 2008)

Total patients collected<smiles>[125Nb]</smiles>

$\downarrow$

Eligible

$(\mathrm{N}=110)$

$\downarrow$

Excluded due to poor material quality

$(\mathrm{N}=20)$<smiles>[AlH2]</smiles>

Tumor content allowing molecular analysis

$(\mathrm{N}=90 ; 87$ analyzed $)$<smiles>[AlH2]</smiles>

Second step (qPCR analysis; year 2012, with longer follow-up)

$(\mathrm{N}=87)$

$\downarrow$

Excluded due to insufficient amount of mRNA $(\mathrm{N}=3)$ or lost to follow-up ( $\mathrm{N}=3)$

$\downarrow$

Analyzed

$(\mathrm{N}=84$; one non analyzable $)$
Validation Cohort B

(material collected 2008-2010)

Total patients collected

$(\mathrm{N}=148)$<smiles>[AlH2]</smiles>

Eligible

$(\mathrm{N}=81)$

$\downarrow$

Excluded due to equivocal HER2 status or poor material quality

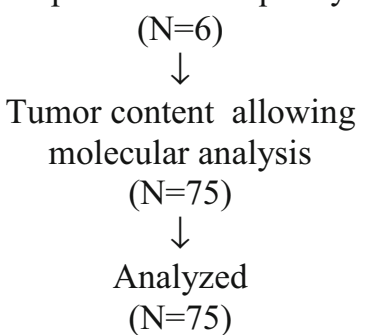

Company, Fair Lawn, NJ) and scraped off from the slide into a microcentrifuge tube. Total RNA was extracted from three $10 \mu \mathrm{m}$ thick whole tissue sections from each sample using the Roche high pure RNA paraffin kit according to manufacturer's instructions (Roche Applied Science, Indianapolis, IN). Purified total RNA samples were stored frozen at $-80{ }^{\circ} \mathrm{C}$ until needed for quality control (QC) analysis and subsequent gene expression profiling and quantitative reverse transcription PCR (qRT-PCR). The concentration of RNA was measured using Nanodrop ${ }^{\circledR}$ ND-1000 spectrophotometer (ThermoScientific, Wilmington, DE). RNA (200 ng) was reverse-transcribed to complementary deoxyribonucleic acid (cDNA) using iScript cDNA synthesis kit (Bio-Rad Laboratories, Inc., Hercules, CA). To prequalify RNA samples, SYBR Green-based qRT-PCR (Applied Biosystems, Foster City, CA) was performed for RPL13A ribosomal protein gene according to Illumina's instructions (San Diego, CA).

DASL analysis

Cohort A samples were analyzed by annealing, selection, extension and ligation (DASL) assay using Cancer Panel v1 to provide expression data on 502 known cancer genes. DASL was performed with the Sentrix universal array (Illumina, San Diego, California) as per the manufacturer's instructions [13] and blinded to patient outcome. Shortly, a $20-\mu \mathrm{l}$ RT reaction containing a reaction mix (MMC; Illumina, San Diego, CA), biotinylated random hexamers and oligo-d(T) ${ }_{18}$, and total RNA, was incubated at room temperature for $10 \mathrm{~min}$ and then at $42{ }^{\circ} \mathrm{C}$ for $1 \mathrm{~h}$. Pooled assay oligos were annealed to their sequence-specific targets on the cDNA under a controlled hybridization program. The cDNA was immobilized on paramagnetic beads and washed to remove any excess or mis-hybridized oligos. Hybridized oligos were then extended and ligated to generate amplifiable templates, using Illumina-supplied reagents and conditions (BeadStation User's Manual, Illumina). A PCR reaction was performed with Cy3 labeled universal PCR primers. Single-stranded PCR products were prepared by denaturation, and were then hybridized to Sentrix arrays under a temperature gradient program. The arrays were imaged using a BeadArray Reader scanner (Illumina). The DASL assay was performed three times independently, and samples were hybridized to three different array matrices. The 502-gene assay was available in 
Table 1 Patient characteristics

\begin{tabular}{|c|c|c|c|c|c|}
\hline \multirow{2}{*}{$\begin{array}{l}\text { Variables } \\
\text { Age at diagnosis }\end{array}$} & \multicolumn{2}{|c|}{$\begin{array}{l}\text { Discovery Cohort A } \\
N=84\end{array}$} & \multicolumn{2}{|c|}{$\begin{array}{l}\text { Validation Cohort B } \\
N=75\end{array}$} & \multirow[t]{2}{*}{$p$} \\
\hline & & & & & \\
\hline Mean & \multicolumn{2}{|l|}{50} & \multicolumn{2}{|l|}{52} & \multirow[t]{2}{*}{0.07} \\
\hline Range & \multicolumn{2}{|l|}{$29-75$} & \multicolumn{2}{|l|}{$28-71$} & \\
\hline \multicolumn{6}{|l|}{ Age at brain metastases } \\
\hline Mean & \multicolumn{2}{|l|}{47.6} & \multicolumn{2}{|l|}{51.5} & \multirow[t]{2}{*}{0.03} \\
\hline \multirow[t]{2}{*}{ Range } & \multicolumn{2}{|l|}{$30-64$} & \multicolumn{2}{|l|}{$33-69$} & \\
\hline & $N$ & $\%$ & $N$ & $\%$ & \\
\hline \multicolumn{6}{|l|}{ Brain metastases } \\
\hline No & 36 & 43 & 34 & 45 & \multirow[t]{2}{*}{0.75} \\
\hline Yes & 48 & 57 & 41 & 55 & \\
\hline \multicolumn{6}{|l|}{ Menopausal status } \\
\hline Premenopausal & 43 & 51 & 28 & 37 & \multirow[t]{2}{*}{0.07} \\
\hline Postmenopausal & 40 & 48 & 47 & 63 & \\
\hline \multicolumn{6}{|l|}{ Histology } \\
\hline Ductal & 70 & 83 & 58 & 77 & \multirow[t]{5}{*}{0.02} \\
\hline Lobular & 6 & 7 & 5 & 7 & \\
\hline Other & 1 & 1 & 3 & 4 & \\
\hline Uncertain & 0 & 0 & 7 & 9 & \\
\hline Ductal and lobular & 6 & 7 & 2 & 3 & \\
\hline \multicolumn{6}{|l|}{ Grades } \\
\hline 2 & 35 & 46 & 34 & 49 & 0.69 \\
\hline 3 & 41 & 54 & 35 & 51 & \\
\hline ER (IHC) & & & & & \\
\hline Negative & 52 & 63 & 43 & 57 & 0.49 \\
\hline Positive & 31 & 37 & 32 & 43 & \\
\hline PR (IHC) & & & & & \\
\hline Negative & 59 & 71 & 54 & 72 & 0.89 \\
\hline Positive & 24 & 29 & 21 & 28 & \\
\hline Breast cancer surgery & & & & & \\
\hline No & 16 & 19 & 15 & 20 & 0.91 \\
\hline Yes & 67 & 81 & 60 & 80 & \\
\hline Radiotherapy & & & & & \\
\hline No & 38 & 46 & 25 & 34 & 0.12 \\
\hline Adjuvant & 27 & 32 & 28 & 37 & \\
\hline Definitive & 0 & 0 & 1 & 1 & \\
\hline Palliative & 13 & 17 & 10 & 13 & \\
\hline Combination thereof & 4 & 5 & 11 & 15 & \\
\hline Chemotherapy induction & & & & & \\
\hline No & 49 & 59 & 55 & 73 & 0.06 \\
\hline Yes & 34 & 41 & 20 & 27 & \\
\hline Chemotherapy & & & & & \\
\hline No & 2 & 2 & 1 & 1 & 0.22 \\
\hline Adjuvant & 11 & 13 & 19 & 25 & \\
\hline For metastatic disease & 15 & 18 & 9 & 12 & \\
\hline Combination thereof & 56 & 67 & 46 & 61 & \\
\hline
\end{tabular}


Table 1 continued

\begin{tabular}{|c|c|c|c|c|c|}
\hline & $N$ & $\%$ & $N$ & $\%$ & \\
\hline \multicolumn{6}{|l|}{ Trastuzumab therapy } \\
\hline No & 13 & 16 & 12 & 16 & \multirow[t]{4}{*}{0.72} \\
\hline Adjuvant & 2 & 2 & 2 & 3 & \\
\hline For metastatic disease & 68 & 81 & 58 & 77 & \\
\hline Combination thereof & 1 & 1 & 3 & 4 & \\
\hline \multicolumn{6}{|c|}{ Anti-HER2 tyrosine kinase inhibitors } \\
\hline No & 72 & 86 & 51 & 68 & \multirow[t]{3}{*}{0.02} \\
\hline Adjuvant & 0 & 0 & 2 & 3 & \\
\hline For metastatic disease & 12 & 14 & 22 & 29 & \\
\hline \multicolumn{6}{|l|}{ Endocrine therapy } \\
\hline No & 44 & 52 & 41 & 55 & \multirow[t]{4}{*}{0.85} \\
\hline Adjuvant/neoadjuvant & 21 & 25 & 21 & 28 & \\
\hline For metastatic disease & 8 & 10 & 6 & 8 & \\
\hline Combination thereof & 11 & 13 & 7 & 9 & \\
\hline \multicolumn{6}{|l|}{ Type of first progression } \\
\hline Local & 2 & 2 & 10 & 13 & \multirow[t]{4}{*}{0.02} \\
\hline Regional & 3 & 4 & 3 & 4 & \\
\hline Distant & 77 & 92 & 56 & 75 & \\
\hline Local/regional and/or distant & 2 & 2 & 6 & 8 & \\
\hline \multicolumn{6}{|c|}{ Dominant site of metastatic disease } \\
\hline Soft tissue & 4 & 5 & 16 & 22 & \multirow[t]{3}{*}{0.001} \\
\hline Bone & 3 & 4 & 7 & 10 & \\
\hline Visceral & 77 & 91 & 50 & 68 & \\
\hline \multicolumn{6}{|c|}{ Location of first extracranial visceral relapse } \\
\hline Lung & 23 & 28 & 25 & 35 & \multirow[t]{6}{*}{0.19} \\
\hline Liver & 34 & 41 & 26 & 36 & \\
\hline Other & 16 & 19 & 15 & 21 & \\
\hline Lung and liver & 8 & 10 & 2 & 3 & \\
\hline Lung and other & 0 & 0 & 3 & 4 & \\
\hline Liver and other & 2 & 2 & 1 & 1 & \\
\hline \multicolumn{6}{|l|}{ Brain as first relapse } \\
\hline No & 77 & 93 & 67 & 89 & \multirow[t]{2}{*}{0.45} \\
\hline Yes & 6 & 7 & 8 & 11 & \\
\hline
\end{tabular}

Significant values marked in bold

$E R$ estrogen receptor, $P R$ progesterone receptor, HER2 human epidermal growth factor receptor 2

a 96-well format; this enabled analysis of all the samples in a single batch. Built-in internal controls and replicate samples were used to analyze stability of the assay. The $r^{2}$ values for the duplicate samples were greater than 0.95 .

Generation of the 13-gene signature

Cohort A samples were divided into an internal training set and an internal testing set. Predictive analysis of microarray analysis (http://www-stat.stanford.edu/ tibs/PAM/) was performed to identify multigene profiles predictive for BM. The best gene-expression signature was selected based on a built-in 10-fold cross-validation analysis in PAM. Then the gene-signature was output as a single variable from the PAM. Its association with the BM free survival (BMFS) was analyzed in the internal testing set with a Cox regression analysis, in which clinical and demographic variable effects were justified. This analysis was performed with the $\mathrm{R}$ function, coxph. The gene signature construction from the internal training set used the optimal variable selection strategy in PAM, and $p$ value was not considered. Then, the correlation between the gene signature and BMFS was assessed by the Cox regression model, and the $p$ value $<0.05$ was considered as statistically significant. 
Table 2 List of genes constituting a 13-gene profile and TaqMan probes used in qRT-PCR analysis

\begin{tabular}{|c|c|c|c|}
\hline Gene symbols & Gene names & Human assay ID & Amplicon length (bp) \\
\hline$C D K 4$ & Cyclin dependent kinase 4 & Hs00175935_m1 & 65 \\
\hline CCNC & Cyclin C & Hs00193177_m1 & 78 \\
\hline PTK2 & Focal adhesion kinase (protein tyrosine kinase 2) & Hs00178587_m1 & 68 \\
\hline$M Y C$ & v-myc avian myelocytomatosis viral oncogene homolog & Hs99999003_m1 & 65 \\
\hline$B A R D 1$ & $B R C A 1$ associated RING domain 1 & Hs00184427_m1 & 73 \\
\hline RAD51 & RAD51 homolog & Hs00153418_m1 & 58 \\
\hline FANCG & Fanconi anemia group $\mathrm{G}$ & Hs00184947_m1 & 116 \\
\hline PCNA & Proliferating cell nuclear antigen & Hs00696862_m1 & 95 \\
\hline$P R C C$ & Papillary renal cell carcinoma-translocation associated & Hs00410541_m1 & 77 \\
\hline$T P R$ & Translocated promoter region & Hs00162918_m1 & 82 \\
\hline$C T T N$ & Cortactin & Hs00193322_m1 & 81 \\
\hline$D S P$ & Desmoplakin & Hs00189422_m1 & 74 \\
\hline$H D G F$ & Hepatoma-derived growth factor & Hs00610314_m1 & 110 \\
\hline$A C T B$ & Actin, beta, cytoplasmic & Hs00357333_g1 & 77 \\
\hline$G A P D H$ & Glyceraldehyde-3-phosphate dehydrogenase & Hs99999905_m1 & 122 \\
\hline TFRC & Transferrin receptor & Hs99999911_m1 & 105 \\
\hline
\end{tabular}

Selected controls: ACTB, GAPDH, TFRC

Table 3 Factors associated with early brain metastases ( $\leq 36$ months)

\begin{tabular}{|c|c|c|c|c|c|c|}
\hline \multirow[t]{2}{*}{ Variables } & \multicolumn{3}{|c|}{ Univariate analysis } & \multicolumn{3}{|c|}{ Multivariate analysis* } \\
\hline & HR & $95 \% \mathrm{CI}$ & $p$ & HR & $95 \% \mathrm{CI}$ & $p$ \\
\hline \multicolumn{7}{|l|}{ Discovery Cohort A } \\
\hline ER negative versus positive & 3.3 & $1.1-10.0$ & 0.03 & 2.8 & $0.9-9.1$ & 0.07 \\
\hline Visceral site of first distant relapse & 4.5 & $1.9-10.7$ & 0.001 & 7.4 & $2.4-22.3$ & $<0.001$ \\
\hline 13-Gene expression high versus low & 5.6 & $1.9-16.5$ & 0.002 & 8.5 & $2.6-28.0$ & $<0.001$ \\
\hline 3-Gene classifier high versus low & 3.7 & $1.3-11.1$ & 0.01 & 5.3 & $1.6-16.7$ & 0.005 \\
\hline Trastuzumab therapy for metastatic disease no versus yes & 3.3 & $1.1-10.0$ & 0.02 & 5.0 & $1.4-10.0$ & 0.009 \\
\hline \multicolumn{7}{|l|}{ Validation Cohort B } \\
\hline ER negative versus positive & 2.5 & $0.9-10.0$ & 0.09 & 5.0 & $1.1-10.0$ & 0.04 \\
\hline Visceral site of first distant relapse & 5.9 & $1.8-19.7$ & 0.003 & 6.1 & $1.5-25.6$ & 0.01 \\
\hline 3-Gene classifier high versus low & 1.2 & $0.3-20.0$ & 0.8 & $\mathrm{NC}$ & & \\
\hline Grade high versus low & 3.3 & $1.1-14.3$ & 0.03 & 3.8 & $0.9-16.7$ & 0.07 \\
\hline Trastuzumab therapy for metastatic disease no versus yes & 2.5 & $1.0-10.0$ & 0.06 & 10.0 & $2.0-100.0$ & 0.008 \\
\hline
\end{tabular}

Real-time qRT-PCR analysis

Owing to the abandoning of the 502-gene DASL assay by the manufacturer, and to increase the potential utility of the profile, we switched to a qRT-PCR assay. Apart from its clinical applicability, this method allows precise quantification of transcriptional abundance of identified genes. TaqMan reactions were performed in triplicates using custom array microfluidic cards preloaded with TaqMan gene expression assays containing 16 genes (13 discriminant genes and 3 reference genes) on an ABI Prism
$7900 \mathrm{HT}$ fast real-time platform according to the manufacturer's instructions. The primer sequences are listed in Table 2. Transferrin receptor (TFRC), beta cytoskeletal actin $(A C T B)$ and glyceraldehyde-3-phosphate dehydrogenase $(G A P D H)$ were used as endogenous reference controls for normalization. Delta threshold cycle $\left(\Delta C_{t}\right)$ values for each of the 13 genes of interest were normalized using the three endogenous reference controls according to the method of Applied Biosystem's DataAssist ${ }^{\mathrm{TM}}$ Software. All procedures were performed blinded to patient outcomes. After normalization, $2^{-\Delta \mathrm{C}_{\mathrm{t}}}$ values were subject to 
Fig. 2 Cohort A. Distribution of the 13 gene transcript expression obtained from the RNA isolation process in DASL and qRT-PCR. a DASL (data was normalized using quantile normalization), b qRT-PCR normalized using the endogenous reference controls (ACTB, GAPDH, TFRC). The graph shows apparent interpanel discordance of $B A R D 1$, $C C N C$ and $H D G F$ expression, and minor inter-panel discordance of FANCG and PCNA expression
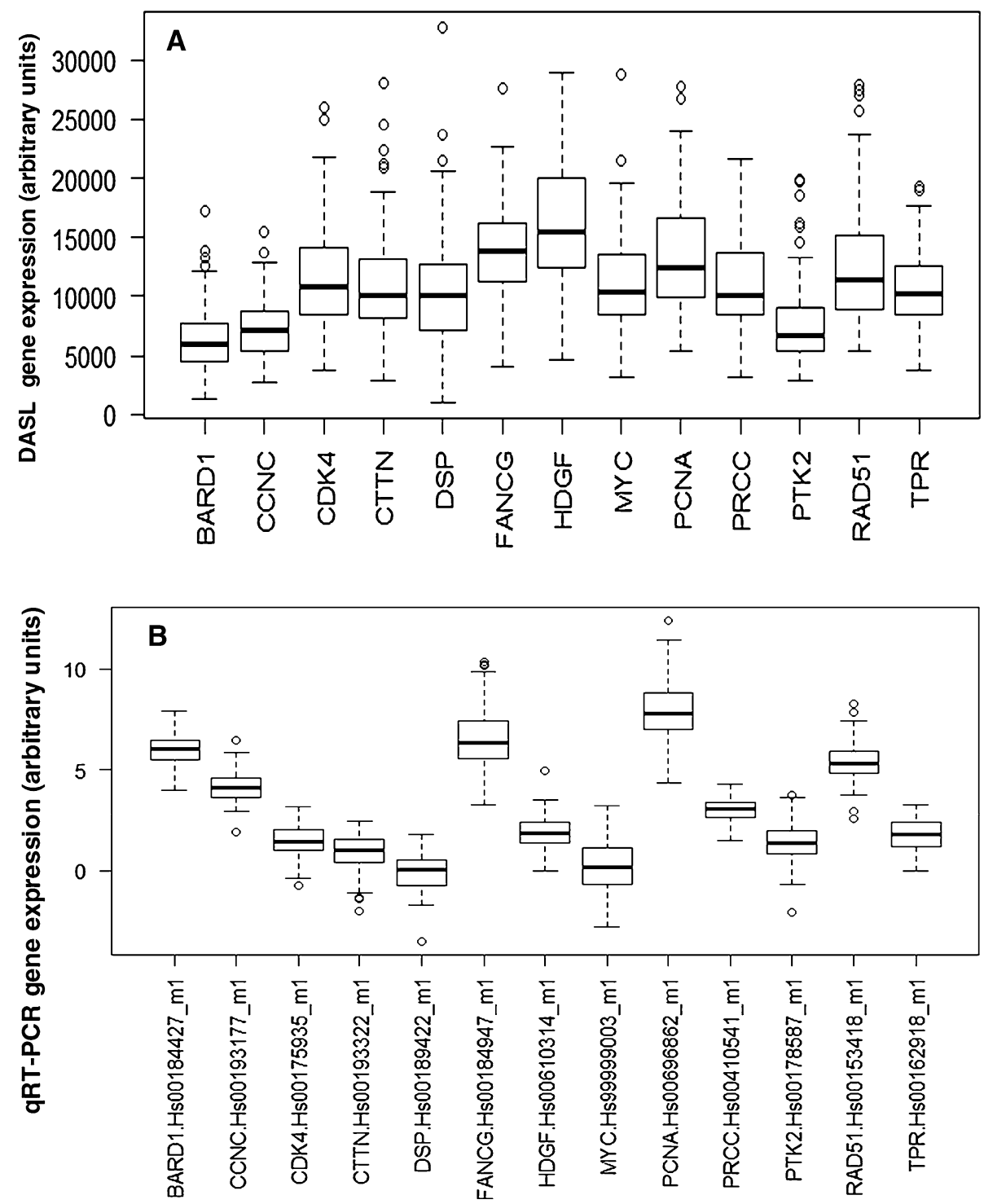

the leave-one-out cross-validated linear discriminant analysis (LDA), and coefficients for the individual genes were chosen. The coefficients for the individual genes and individual gene expression data for each patient were collated to develop an individual score, which was used for statistical analysis in both cohorts.

\section{Statistical analysis}

All statistical analyses were performed using STATA software version 11. Statistical significance was defined as $p<0.05$. Gene expression data were normalized at the median level. Hierarchical clustering and singular value decomposition methods were applied to detect the outliers for QC purposes. The false discovery rate (FDR), an estimate of the proportion of errors committed by falsely rejecting null hypotheses was calculated for each gene. Categorical variables in both cohorts (including correlation of the developed 3-gene classifier with clinicopathologic variables) were compared using Pearson's Chi squared test $\left(\chi^{2}\right)$. Survival curves were plotted using Kaplan-Meier method starting from date of primary breast cancer diagnosis to date of death or last follow-up. The BMFS was a primary endpoint and was defined from date of primary breast cancer diagnosis to date of BM diagnosis, death of any cause, or date of last follow-up. Univariate survival analysis and time to diagnosis of BM within 36 months in Cohorts A and B were performed with log-rank test, Wilcoxon test and Cox proportional hazard regression and controlled for the competing risk of death [14]. Multivariate analysis used a stepwise forward selection of univariate model with $p \leq 0.20$. 
Table 4 Relationship between the 3-gene classifier and other variables
Significant values marked in bold

$E R$ estrogen receptor, $P R$ progesterone receptor, HER2 human epidermal growth factor receptor 2

\begin{tabular}{|c|c|c|c|c|c|c|c|c|c|c|}
\hline \multirow[t]{4}{*}{ Variables } & \multicolumn{10}{|c|}{ 3-Gene classifier } \\
\hline & \multicolumn{5}{|c|}{ Discovery Cohort A $(N=83)$} & \multicolumn{5}{|c|}{ Validation Cohort $\mathrm{B}(N=75)$} \\
\hline & \multicolumn{2}{|c|}{$\begin{array}{l}\text { Low } \\
(N=34 ; 41 \%)\end{array}$} & \multicolumn{3}{|c|}{$\begin{array}{l}\text { High } \\
(N=49 ; 59 \%)\end{array}$} & \multicolumn{2}{|c|}{$\begin{array}{l}\text { Low } \\
(N=63 ; 84 \%)\end{array}$} & \multicolumn{3}{|c|}{$\begin{array}{l}\text { High } \\
(N=12 ; 16 \%)\end{array}$} \\
\hline & $N$ & $\%$ & $N$ & $\%$ & $p$ & $N$ & $\%$ & $N$ & $\%$ & $p$ \\
\hline \multicolumn{11}{|l|}{ Menopausal status } \\
\hline Premenopausal & 20 & 60 & 23 & 47 & & 24 & 38 & 4 & 33 & 0.75 \\
\hline Postmenopausal & 13 & 40 & 26 & 53 & 0.22 & 39 & 62 & 8 & 67 & \\
\hline \multicolumn{11}{|c|}{ Primary tumor grades } \\
\hline 2 & 20 & 67 & 15 & 33 & & 28 & 49 & 6 & 50 & 0.95 \\
\hline 3 & 10 & 33 & 30 & 67 & 0.05 & 29 & 51 & 6 & 50 & \\
\hline \multicolumn{11}{|l|}{ ER } \\
\hline Negative & 16 & 47 & 36 & 75 & & 35 & 56 & 8 & 67 & 0.47 \\
\hline Positive & 18 & 53 & 12 & 25 & 0.01 & 28 & 44 & 4 & 33 & \\
\hline \multicolumn{11}{|l|}{ PR } \\
\hline Negative & 23 & 68 & 36 & 75 & & 45 & 71 & 9 & 75 & 0.80 \\
\hline Positive & 11 & 32 & 12 & 25 & 0.46 & 18 & 29 & 3 & 25 & \\
\hline \multicolumn{11}{|c|}{ Induction chemotherapy } \\
\hline No & 21 & 62 & 28 & 58 & & 50 & 79 & 5 & 42 & 0.007 \\
\hline Yes & 13 & 38 & 20 & 42 & 0.75 & 13 & 21 & 7 & 58 & \\
\hline \multicolumn{11}{|l|}{ Endocrine therapy } \\
\hline No & 12 & 36 & 31 & 63 & & 33 & 52 & 8 & 67 & 0.36 \\
\hline Yes & 22 & 65 & 18 & 37 & $\mathbf{0 . 0 1}$ & 30 & 48 & 4 & 33 & \\
\hline \multicolumn{11}{|c|}{ Trastuzumab for metastatic disease } \\
\hline No & 3 & 9 & 13 & 26 & & 15 & 24 & 2 & 17 & 0.59 \\
\hline Yes & 31 & 91 & 36 & 73 & $\mathbf{0 . 0 4}$ & 48 & 76 & 10 & 83 & \\
\hline \multicolumn{11}{|c|}{ Visceral location of first relapse } \\
\hline No & 31 & 94 & 34 & 69 & & 44 & 73 & 9 & 75 & 0.90 \\
\hline Yes & 2 & 6 & 15 & 31 & $\mathbf{0 . 0 1}$ & 16 & 27 & 3 & 25 & \\
\hline \multicolumn{11}{|c|}{ First site of visceral metastasis } \\
\hline Lung & 11 & 33 & 12 & 25 & & 22 & 37 & 3 & 25 & 0.05 \\
\hline Liver & 16 & 48 & 18 & 37 & & 22 & 37 & 4 & 33 & \\
\hline Other & 2 & 6 & 13 & 27 & & 13 & 22 & 2 & 17 & \\
\hline Lung and liver & 4 & 12 & 4 & 8 & & 0 & 0 & 2 & 17 & \\
\hline Lung and other & 0 & 0 & 0 & 0 & & 2 & 3 & 1 & 8 & \\
\hline Liver and other & 0 & 0 & 2 & 4 & 0.19 & 1 & 2 & 0 & 0 & \\
\hline \multicolumn{11}{|l|}{ Brain metastases } \\
\hline No & 11 & 32 & 25 & 51 & & 28 & 44 & 6 & 50 & \\
\hline Yes & 23 & 67 & 24 & 49 & 0.09 & 35 & 55 & 6 & 50 & 0.72 \\
\hline
\end{tabular}

\section{Results}

Characteristics and outcomes of study cohorts

\section{Discovery Cohort A}

Of the 84 primary tumors subjected to analysis in the Cohort A, 83 were analyzable (Fig. 1). The patient mean age was 48 years (range 30-64), with the patients roughly divided between pre- and post-menopausal status (Table 1). Eighty three percent of the tumors were invasive ductal cancers, $63 \%$ were ER-negative and $71 \%$ PRnegative. Ninety two percent of patients had dominant visceral metastatic disease; $98 \%$ of patients received chemotherapy and $48 \%$ endocrine therapy in adjuvant and/or metastatic setting. More than $40 \%$ of patients received induction chemotherapy and $87 \%$ of patients were administered trastuzumab in adjuvant or metastatic 
setting, usually in combination with chemotherapy. In $14 \%$ of patients lapatinib was administered at trastuzumab relapse. Follow-up from breast cancer diagnosis varied from 1 to 185 months. Within this period, 48 patients developed symptomatic BM. The median time from initial breast cancer to $\mathrm{BM}$ diagnosis was 36 months (range 2-141 months). In $7 \%$ of patients brain was the first site of distant relapse, with or without accompanying extracranial relapse. After BM, HER2 directed treatments included trastuzumab (33\% of patients), lapatinib (15\%) and either used sequentially (4\%). Seventy seven percent of patients received cranial radiotherapy. The median overall survival (OS) from the initial diagnosis of breast cancer was 44 months (range 0.9-185 months).

\section{Validation Cohort B}

The Cohort B, including 75 analyzable cases, was similar to Cohort $\mathrm{A}$ in terms of age, ER and PR expression, and tumor grade (Table 1). However, Cohort B included significantly more non-ductal cancers, patients were older at BM development and had different patterns of relapse (fewer distant relapses as the first failure, more first relapses in the visceral organs and fewer visceral dominant metastatic sites). Furthermore, more patients in this cohort received lapatinib following failure of trastuzumab. The median time to diagnosis of BM in this cohort was longer (40 months; range 0.33-125 months, compared to 36 months in Cohort A), and so was the median OS (50 months; range 11-186 months, compared to 44 months in Cohort A). In Cohort B 41 patients developed BM, including 16 that occurred within 36 months from diagnosis.

\section{Determinants of BMFS and OS}

Performed in Cohort A binary comparison for presence or absence of BM among 502 analyzed genes did not show any differential gene expression (25 having $p<0.05$, a FDR of 1.0). However, a gene expression analysis in 22 and 21 patients who developed BM within 36 months (the median time to diagnosis of BM) versus thereafter, respectively, identified differential expression of 48 genes with $p<0.01$ and $\mathrm{FDR}=0.1$. Predictive analysis of microarray analysis identified a 13-gene profile [cyclin dependent kinase $4(C D K 4)$, cyclin $\mathrm{C}(C C N C)$, focal adhesion kinase (protein tyrosine kinase 2, PTK2), v-myc avian myelocytomatosis viral oncogene homolog (MYC), BRCA1 associated RING domain 1 (BARD1), RAD51 homolog (RAD51), Fanconi anemia group G (FANCG), proliferating cell nuclear antigen $(P C N A)$, papillary renal cell carcinoma-translocation associated (PRCC), translocated promoter region $(T P R)$, cortactin (CTTN), desmoplakin $(D S P)$, hepatoma-derived growth factor $(H D G F)]$ at effectively distinguished patients with early versus late BM [hazard ratio (HR) 5.6, $95 \%$ CI 1.9-16.5; $p=0.002$ in the univariate analysis; HR $8.5,95 \% \mathrm{CI}$ 2.6-28.0; $p<0.001$ in the multivariate analysis; Table 3]. The microarray data have been deposited in NCBI's gene expression omnibus (http://www.ncbi.nlm.nih.gov/geo; GSE38057).

In order to increase the potential clinical applicability of this signature, a qRT-PCR based analysis of the 13 genes (and 3 references) was performed and showed promising preliminary results $[15,16]$. The TaqMan gene expression assay IDs for each gene was chosen to meet FFPE sample requirements for custom TLDA based on Applied Biosystems guidelines. As expected, DASL and qRT-PCR had inherent differences related to the platform (Fig. 2). As the next step, a leave-one-out LDA was performed using an updated database that had a longer follow-up (5 years) data. A predictive model that included only 3 of the original 13 genes: $H D G F, R A D 51$ and TPR, with corresponding LDA coefficients of 1.06, 0.35 and -1.08 , respectively, was developed. The 3-gene classifier was highly predictive of early BM both in univariate (HR 3.7, $95 \%$ CI $1.3-11.1 ; p=0.01)$ and multivariate analysis (HR 5.3, $95 \%$ CI 1.6-16.7; $p=0.005$; Table 3). High 3 -gene classifier was associated with tumor grade 3, ERnegativity and less frequent use of endocrine treatment and trastuzumab in the adjuvant and/or metastatic setting (Table 4). Additionally, patients with high 3-gene classifier were more likely to develop the first relapse in the visceral organs.

In an independent Cohort B the mean qRT-PCR expression of 13 genes was different compared to Cohort A, and only $16 \%$ of patients (compared to $59 \%$ in Cohort A) were assigned to the high-risk group (Table 4). Accordingly, the 3-gene classifier was not predictive of early BM (HR 1.2, $95 \%$ CI 0.3-20.0; $p=0.8$; Table 3). In this cohort the high 3-gene classifier was associated with less frequent use of induction chemotherapy and more lung and liver metastases (Table 4).

In the multivariate analysis, in both cohorts the visceral location of first distant relapse (Cohort A: HR 7.4, $95 \% \mathrm{CI}$ 2.4-22.3; $p<0.001$; Cohort B: HR 6.1, $95 \%$ CI 1.5-25.6; $p=0.01)$ and the lack of trastuzumab administration in the metastatic setting (HR 5.0, $95 \%$ CI 1.4-10.0; $p=0.009$ and HR 10.0, $95 \%$ CI 2.0-100.0; $p=0.008$, respectively) correlated with early BM (Table 3). ER-negativity had a strong trend in Cohort A (HR 2.8, $95 \%$ CI 0.9-9.1; $p=0.07$ ) and was significant in Cohort B (HR 5.0, $95 \%$ CI $1.1-10.0 ; p=0.04)$.

In both cohorts the independent variables associated with shorter OS included higher tumor grade (HR 1.9, $95 \%$ CI $1.1-3.3 ; p=0.02$; HR 1.9, $95 \%$ CI 1.4-3.2; 
$p=0.03$ ), ER negativity (HR 2.0, $95 \%$ CI 1.1-3.3; $p=0.03$; HR 2.5, $95 \%$ CI $1.4-5.0 ; p<0.01)$ and the lack of primary tumor surgery (HR 5.0, $95 \%$ CI 2.0-10.0; $p<0.01$; HR 3.3, $95 \%$ CI $1.7-10.0 ; p<0.01$ ).

\section{Discussion}

The aim of this study was to identify molecular predictors of the BM development in advanced HER2-positive breast cancer patients. This subset of breast cancer patients carry particularly high risk of BM. Additionally, some studies suggested increased risk of BM associated with the use of trastuzumab [17].

The current study employed a high throughput DASL technology based on the expression of 502 cancer related genes in addition to analysis of the clinicopathologic variables. This targeted gene analysis did not demonstrate any differential gene expression in patients who did and did not develop BM. This may likely be due to the limited number of genes analyzed, but it is also possible that BM in advanced HER2-positive breast cancer patients is a biologically determined, stochastic and inevitable event. Further analysis of the DASL led to identification of a 13-gene profile that was apparently predictive for development of early BM [15]. For precise quantification of transcriptional abundance of identified genes, we employed qRT-PCR technology, which identified a 3-gene classifier (RAD51, $H D G F, T P R)$, also seemingly predictive for early BM. However, the significance of this classifier was not confirmed in the independent cohort.

The retrospective design of this study made it difficult to control for major clinicopathologic differences between Cohorts A and B. In consequence, patients in Cohort B had fewer ductal carcinomas and, even more importantly, less frequently received neoadjuvant chemotherapy. Gene expression alterations of breast cancer were recently demonstrated to be drug-specific, and drug-induced tumor gene signatures may be more informative than unchallenged signatures in predicting treatment outcomes [18, 19]. The study by Bos et al. [20] showed that BM gene set tested in various breast cancer cohorts was less BM predictive in patients whom received postoperative systemic therapy compared to those whom did not. This confirms the hypothesis that systemic therapies, apart from their preventive effect, may also alter the pattern of relapse in breast cancer. In this study, patients in Cohort B, compared to Cohort $\mathrm{A}$, had also infrequent first relapse at distant sites and significantly fewer visceral metastases. Furthermore, much more patients in this cohort received lapatinib at trastuzumab relapse (32\%, compared to $14 \%$ in Cohort A). The pivotal study by Geyer et al. [21] showed that the addition of lapatinib to capecitabine after progression on trastuzumab resulted in decreased BM occurrence, and preclinical studies show that lapatinib prevents BMs formation by $53 \%$ in a HER2-transfected model system [22]. The abovementioned differences between both cohorts led to better general prognosis in Cohort B compared to Cohort $\mathrm{A}$, expressed by longer OS and time to diagnosis of BM. Finally, the imbalanced proportion of patients with high gene classifier in both cohorts (59\% in Cohort A vs. $16 \%$ in Cohort B) might have largely impacted study results.

Although the gene signature could not be validated, it identified a number of genes that could be important in the development of BM. The most important of which is $R A D 51$, a gene involved in homologous recombination in DNA double strand breaks repair [20]. RAD51 expression has been linked to response to neoadjuvant therapy [2325]. We have previously reported that high cytoplasmic expression of RAD51 in breast cancer is associated with significantly increased risk of BM, particularly in combination with high Ki-67 index and ER-negativity [26]. Further, in other study demonstrated that BARD1 and RAD51 are frequently overexpressed in BMs from breast cancer and may constitute a mechanism to overcome reactive oxygen species-mediated genotoxic stress in the metastatic brain [27]. Taken together, this data suggest that RAD51 targeting might be important in HER2-positive breast cancer. High nuclear expression of $H D G F$, another gene constituting our 3-gene signature, was earlier found to associate with high tumor grade, Ki-67 $>20 \%$, lymph node involvement and poor prognosis in breast cancer patients [28, 29]. Chen et al. [29] demonstrated that nuclear HDGF over-expression stimulates epithelial-mesenchymal transition of breast cancer cells by down-regulation of E-cadherin and up-regulation of vimentin. The third gene of our signature- $T P R$, a translocated promoter region nuclear basket protein, is poorly characterized but has a normal function in nuclear pore function and is the target of oncogenic fusions [30].

In the current study, the clinical factors associated with early development of BM were visceral location of first relapse and, at a borderline level, ER-negativity, the two hallmarks of tumor aggressiveness. This is partly consistent with our earlier study in advanced HER2-positive breast cancer patients, showing the association between the risk of $\mathrm{BM}$ and shorter time to first extracranial progression [5]. The association between ER-negativity and the occurrence of BM in HER2-positive breast cancer patients was earlier reported by other authors $[2,4,31,32]$. Indeed, the clinical behavior including tumor kinetics and sites of recurrence in ER-positive/HER2 positive (HER2-positive luminal B) breast cancer is different compared to that in non-luminal HER2 enriched subtype [31-34]. We also showed that trastuzumab administration in the metastatic setting may reduce the risk of early BM. This is in line with two other 
studies, that noticed shorter time to development of BM in HER2-positive patients who never received trastuzumab $[35,36]$.

\section{Conclusions}

We demonstrated that the presence of visceral metastases and the lack of trastuzumab administration in the metastatic setting apparently increase the likelihood of early BM in advanced HER2-positive breast cancer, and the 3-gene classifier does not improve their predictive value. Our study also illustrates the difficulties in developing clinically useful predictive markers in the retrospective setting [37]. In our case these included problems associated with archival tissue collection, heterogeneity of patient populations and inconsistent therapeutic approaches over the study period. Further studies, including larger and more homogeneous groups, are necessary to identify biomarkers, which may help in designing BM preventive trials and prompt new treatment strategies.

Acknowledgments This work was supported by the US Department of Defense Breast Cancer Research Program, Grant Number W81 XWH-062-0033. Additional support was from the Intramural Research Programs of the National Cancer Institute in Bethesda, USA and Medical University of Gdańsk, Poland.

Conflict of interest GWS and SB were supported by the Susan G Komen For the Cure ${ }^{\circledR}$. The authors indicated no potential competing interests.

Open Access This article is distributed under the terms of the Creative Commons Attribution License which permits any use, distribution, and reproduction in any medium, provided the original author(s) and the source are credited.

\section{References}

1. Bendell J, Domchek S, Burstein H, Harris L, Younger J, Kuter I, Bunnell C, Rue M, Gelman R, Winer E (2003) Central nervous system metastases in women who receive trastuzumab-based therapy for metastatic breast carcinoma. Cancer 97:2972-2977

2. Clayton A, Danson S, Jolly S, Ryder WD, Burt PA, Stewart AL, Wilkinson PM, Welch RS, Magee B, Wilson G, Howell A, Wardley AM (2004) Incidence of cerebral metastases in patients treated with trastuzumab for metastatic breast cancer. Br J Cancer 91:639-643

3. Stemmler HJ, Kahlert S, Siekiera W, Untch M, Heinrich B, Heinemann V (2006) Characteristics of patients with brain metastases receiving trastuzumab for HER2 overexpressing metastatic breast cancer. Breast 15:219-225

4. Brufsky A, Mayer M, Rugo H, Kaufman PA, Tan-Chiu E, Tripathy D, Tudor IC, Wang LI, Brammer MG, Shing M, Yood MU, Yardley DA (2011) Central nervous system metastases in patients with HER2-positive metastatic breast cancer: incidence, treatment, and survival in patients from registHER. Clin Cancer Res 17:4834-4843

5. Duchnowska R, Dziadziuszko R, Czartoryska-Arlukowicz B, Radecka B, Szostakiewicz B, Sosińska-Mielcarek K, Karpińska
A, Starosławska E, Kubiatowski T, Szczylik C (2009) Risk factors for brain relapse in HER2-positive metastatic breast cancer patients. Breast Cancer Res Treat 117:297-303

6. Slamon D, Leyland-Jones B, Shak S, Fuchs H, Paton V, Bajamonde A, Fleming T, Eiermann W, Wolter J, Pegram M, Baselga J, Norton L (2001) Use of chemotherapy plus a monoclonal antibody against HER2 for metastatic breast cancer that overexpresses HER2. N Engl J Med 344:783-792

7. Romond EH, Perez EA, Bryant J, Suman VJ, Geyer CE Jr, Davidson NE, Tan-Chiu E, Martino S, Paik S, Kaufman PA, Swain SM, Pisansky TM, Fehrenbacher L, Kutteh LA, Vogel VG, Visscher DW, Yothers G, Jenkins RB, Brown AM, Dakhil SR, Mamounas EP, Lingle WL, Klein PM, Ingle JN, Wolmark N (2005) Trastuzumab plus adjuvant chemotherapy for operable HER2-positive breast cancer. N Engl J Med 353:1673-1684

8. Piccart-Gebhart MJ, Procter M, Leyland-Jones B, Goldhirsch A, Untch M, Smith I, Gianni L, Baselga J, Bell R, Jackisch C, Cameron D, Dowsett M, Barrios CH, Steger G, Huang CS, Andersson M, Inbar M, Lichinitser M, Láng I, Nitz U, Iwata H, Thomssen C, Lohrisch C, Suter TM, Rüschoff J, Suto T, Greatorex V, Ward C, Straehle C, McFadden E et al (2005) Trastuzumab after adjuvant chemotherapy in HER2-positive breast cancer. N Engl J Med 353:1659-1672

9. Joensuu H, Kellokumpu-Lehtinen PL, Bono P, Alanko T, Kataja V, Asola R, Utriainen T, Kokko R, Hemminki A, Tarkkanen M, Turpeenniemi-Hujanen T, Jyrkkiö S, Flander M, Helle L, Ingalsuo S, Johansson K, Jääskeläinen AS, Pajunen M, Rauhala M, Kaleva-Kerola J, Salminen T, Leinonen M, Elomaa I, Isola J, FinHer Study Investigators (2006) Adjuvant docetaxel or vinorelbine with or without trastuzumab for breast cancer. N Engl J Med 354:809-820

10. Slamon D, Eiermann W, Robert N, Pienkowski T, Martin M, Press M, Mackey J, Glaspy J, Chan A, Pawlicki M, Pinter T, Valero V, Liu MC, Sauter G, von Minckwitz G, Visco F, Bee V, Buyse M, Bendahmane B, Tabah-Fisch I, Lindsay MA, Riva A, Crown J, Breast Cancer International Research Group (2011) Adjuvant trastuzumab in HER2-positive breast cancer. N Engl J Med 365:1273-1283

11. Stemmler H-J, Schmitt M, Willems A, Bernhard H, Harbeck N, Heinemann V (2007) Ratio of trastuzumab levels in serum and cerebrospinal fluid is altered in HER2-positive breast cancer patients with brain metastases and impairment of the blood-brain barrier. Anticancer Drugs 18:23-28

12. Rozencweig M, Heuson JC (1975) Breast cancer: prognostic factors and clinical evaluation. In: Staquet MJ (ed) Cancer Therapy: prognostic factors and criteria of response. Raven Press, New York, p 171

13. Bibikova M, Talantov D, Chudin E, Yeakley JM, Chen J, Doucet D, Wickham E, Atkins D, Barker D, Chee M, Wang Y, Fan JB (2004) Quantitative gene expression profiling in formalin-fixed, paraffin-embedded tissues using universal bead arrays. Am J Pathol 165:1799-1807

14. Scrucca L, Santucci A, Aversa F (2007) Competing risk analysis using R: an easy guide for clinicians. Bone Marrow Transplant 40:381-387

15. Duchnowska R, Jassem J, Thorat M, Morimiya A, Li L, Sledge GW Jr, Biernat W, Szczylik C, Steeg P, Badve S (2008) Gene expression analysis for prediction of rapid brain metastasis in HER2-positive breast cancer patients [abstract]. J Clin Oncol 26:s45

16. Duchnowska R, Jassem J, Pankaj Goswami C, Gokmen-Polar Y, Li L, Thorat MA, Flores N, Hua E, Woditschka S, Palmieri D, Steinberg SM, Biernat W, Sosinska-Mielcarek K, Szostakiewicz B, Czartoryska-Arlukowicz B, Radecka B, Tomasevic Z, Sledge GW, Steeg PS, Badve SS, Polish Brain Metastasis Consortium (2012) 13-Gene signature to predict rapid development of brain 
metastases in patients with HER2-positive advanced breast cancer [abstract]. J Clin Oncol 30(Suppl):505

17. Duchnowska R, Szczylik C (2005) Central nervous system metastases in breast cancer patients administered trastuzumab. Cancer Treat Rev 31:312-318

18. Lee SC, Xu X, Lim YW, Iau P, Sukri N, Lim SE, Yap HL, Yeo WL, Tan P, Tan SH, McLeod H, Goh BC (2009) Chemotherapyinduced tumor gene expression changes in human breast cancers. Pharmacogenet Genomics 19:181-192

19. Lee SC, Xu X, Chng WJ, Watson M, Lim YW, Wong CI, Iau P, Sukri N, Lim SE, Yap HL, Buhari SA, Tan P, Guo J, Chuah B, McLeod HL, Goh BC (2009) Post-treatment tumor gene expression signatures are more predictive of treatment outcomes than baseline signatures in breast cancer. Pharmacogenet Genomics 19:833-842

20. Bos PD, Zhang XH, Nadal C, Shu W, Gomis RR, Nguyen DX, Minn AJ, van de Vijver MJ, Gerald WL, Foekens JA, Massagué J (2009) Genes that mediate breast cancer metastasis to the brain. Nature 459:1005-1009

21. Geyer CE, Forster J, Lindquist D, Chan S, Romieu CG, Pienkowski T, Jagiello-Gruszfeld A, Crown J, Chan A, Kaufman B, Skarlos D, Campone M, Davidson N, Berger M, Oliva C, Rubin SD, Stein S, Cameron D (2006) Lapatinib plus capecitabine for HER2-positive advanced breast cancer. N Engl J Med 355:2733-2743

22. Gril B, Palmieri D, Bronder JL, Herring JM, Vega-Valle E, Feigenbaum L, Liewehr DJ, Steinberg SM, Merino MJ, Rubin SD, Steeg PS (2008) Effect of lapatinib on the outgrowth of metastatic breast cancer cells to the brain. J Natl Cancer Inst 100:1092-1103

23. Kim TM, Ko JH, Hu L, Kim SA, Bishop AJ, Vijg J, Montagna C, Hasty P (2012) RAD51 mutants cause replication defects and chromosomal instability. Mol Cell Biol 32:3663-3680

24. Graeser M, McCarthy A, Lord C, Savage K, Hills M, Salter J, Orr N, Parton M, Smith IE, Reis-Filho JS, Dowsett M, Ashworth A, Turner NC (2010) A marker of homologous recombination predicts pathologic complete response to neoadjuvant chemotherapy in primary breast cancer. Clin Cancer Res 16:6159-6168

25. Asakawa H, Koizumi H, Koike A, Takahashi M, Wu W, Iwase H, Fukuda M, Ohta T (2010) Prediction of breast cancer sensitivity to neoadjuvant chemotherapy based on the status of DNA damage repair proteins. Breast Cancer Res 12:R17

26. Sosińska-Mielcarek K, Duchnowska R, Winczura P, Badzio A, Majewska H, Lakomy J, Pęksa R, Pieczyńska B, Radecka B, Dębska S, Biernat W, Jassem J (2013) Immunohistochemical prediction of brain metastases in patients with advanced breast cancer: the role of RAD51. Breast 22:1178-1183

27. Woditschka S, Evans L, Duchnowska R, Reed LT, Palmieri D, Qian Y, Badve S, Sledge G Jr, Gril B, Aladjem MI, Fu H, Flores
NM, Gökmen-Polar Y, Biernat W, Szutowicz-Zielińska E, Mandat T, Trojanowski T, Och W, Czartoryska-Arlukowicz B, Jassem J, Mitchell JB, Steeg PS (2014) DNA double-strand break repair genes and oxidative damage in brain metastasis of breast cancer. J Natl Cancer Inst 106(7):dju145

28. Chen X, Yun J, Fei F, Yi J, Tian R, Li S, Gan X (2012) Prognostic value of nuclear hepatoma-derived growth factor (HDGF) localization in patients with breast cancer. Pathol Res Pract 208:437-443

29. Chen SC, Kung ML, Hu TH, Chen HY, Wu JC, Kuo HM, Tsai HE, Lin YW, Wen ZH, Liu JK, Yeh MH, Tai MH (2012) Hepatoma-derived growth factor regulates breast cancer cell invasion by modulating epithelial-mesenchymal transition. J Pathol 228:158-169

30. Bangs PL, Sparks CA, Odgren PR, Fey EG (1996) Product of the oncogene-activating gene $\mathrm{Tpr}$ is a phosphorylated protein of the nuclear pore complex. J Cell Biochem 61:48-60

31. Vaz-Luis I, Ottesen RA, Hughes ME, Marcom PK, Moy B, Rugo HS, Theriault RL, Wilson J, Niland JC, Weeks JC, Lin NU (2012) Impact of hormone receptor status on patterns of recurrence and clinical outcomes among patients with human epidermal growth factor-2-positive breast cancer in the National Comprehensive Cancer Network: a prospective cohort study. Breast Cancer Res 14:R129

32. Kennecke H, Yerushalmi R, Woods R, Cheang MC, Voduc D, Speers CH, Nielsen TO, Gelmon K (2010) Metastatic behavior of breast cancer subtypes. J Clin Oncol 28:3271-3277

33. Paluch-Shimon S, Ben-Baruch N, Wolf I, Zach L, Kopolovic J, Kruglikova A, Modiano T, Yosepovich A, Catane R, Kaufman B (2009) Hormone receptor expression is associated with a unique pattern of metastatic spread and increased survival among HER2overexpressing breast cancer patients. Am J Clin Oncol 32:504-508

34. Vaz-Luis I, Winer EP, Lin NU (2013) Human epidermal growth factor receptor-2-positive breast cancer: does estrogen receptor status define two distinct subtypes? Ann Oncol 24:283-291

35. Dawood S, Broglio K, Esteva FJ, Ibrahim NK, Kau SW, Islam R, Aldape KD, Yu TK, Hortobagyi GN, Gonzalez-Angulo AM (2008) Defining prognosis for women with breast cancer and CNC metastases by HER2 status. Ann Oncol 19:1242-1248

36. Park IH, Ro J, Lee KS, Nam BH, Kwon Y, Shin KH (2009) Trastuzumab treatment beyond brain progression in HER2-positive metastatic breast cancer. Ann Oncol 20:56-62

37. Diamandis EP (2010) Cancer biomarkers: can we turn recent failures into success? J Natl Cancer Inst 102:1462-1467 